\title{
BMP7 wt Allele
}

National Cancer Institute

\section{Source}

National Cancer Institute. BMP7 wt Allele. NCI Thesaurus. Code C51533.

Human BMP7 wild-type allele is located within $20 q 13$ and is approximately $96 \mathrm{~kb}$ in length.

This allele, which encodes bone morphogenetic protein 7, plays a role in embryogenesis and bone induction. 